\title{
Delayed impacts of land-use via groundwater on Lake Taupo, New Zealand
}

\author{
J. C. Hadfield ${ }^{1}$, U. Morgenstern ${ }^{2}$ \& J. J. Piper ${ }^{3}$ \\ ${ }^{I}$ Environment Waikato, Hamilton East, New Zealand \\ ${ }^{2}$ GNS Science, Avalon, Lower Hut, New Zealand \\ ${ }^{3}$ Tonkin and Taylor Ltd, Auckland, New Zealand
}

\begin{abstract}
The near pristine quality of water in Lake Taupo has begun to deteriorate, largely as a result of farming. Groundwater investigations were undertaken to estimate potential future land-use impacts and the lag in effects. The lake is a sink for groundwater migrating indirectly via baseflow dominated streams and to a lesser extent by direct seepage. Land-use impacts are increasing as contaminated water progressively replaces older, higher quality groundwater.

The age of groundwater in Lake Taupo catchment was estimated by measuring the cosmogenic isotope tritium and atmospheric trace gases CFC and $\mathrm{SF}_{6}$. Mean residence times of samples ranged from about 20 to 75 years. Higher nitrogen concentrations occur in groundwater with a greater fraction of water recharged since farm development some 40 years ago.

Numerical groundwater modeling predicts nitrogen mass loading to the lake from current land-use will continue to increase for a substantial period of time ( $>100$ years). This lag relates to the considerable time required to replace old pristine groundwater with nitrogen enriched water from farming. Modeled nitrogen flux via groundwater of some 300 tonnes annually may potentially be expected, with 25,000 tonnes stored in the groundwater system. A proposed initiative to reduce manageable nitrogen loading from the catchment by $20 \%$ would be a useful mitigation measure.
\end{abstract}

Keywords: groundwater, diffuse contamination, dating, lag, nitrogen, model, Lake Taupo. 


\section{Introduction}

Lake Taupo is a large $\left(622 \mathrm{~km}^{2}\right)$ oligotrophic lake in the central North Island, New Zealand, which occupies a volcanic collapse caldera, fig. 1. Although water quality in the lake is very high, there is evidence of decline (Gibbs [1]). Nutrient loads from inflowing streams have also increased (Vant and Smith [2]). Historically the lake has extremely low levels of nitrogen which has limited the growth of aquatic plants in its waters. Much of the traditional scrubland around the lake has, however, been converted for agricultural use over about the last 40 years. This has led to increases in nitrogen being leached and transported to the lake. The northern and western catchments are the primary focus of study given their greater potential for land-use intensification (Ministry of Agriculture [3]).

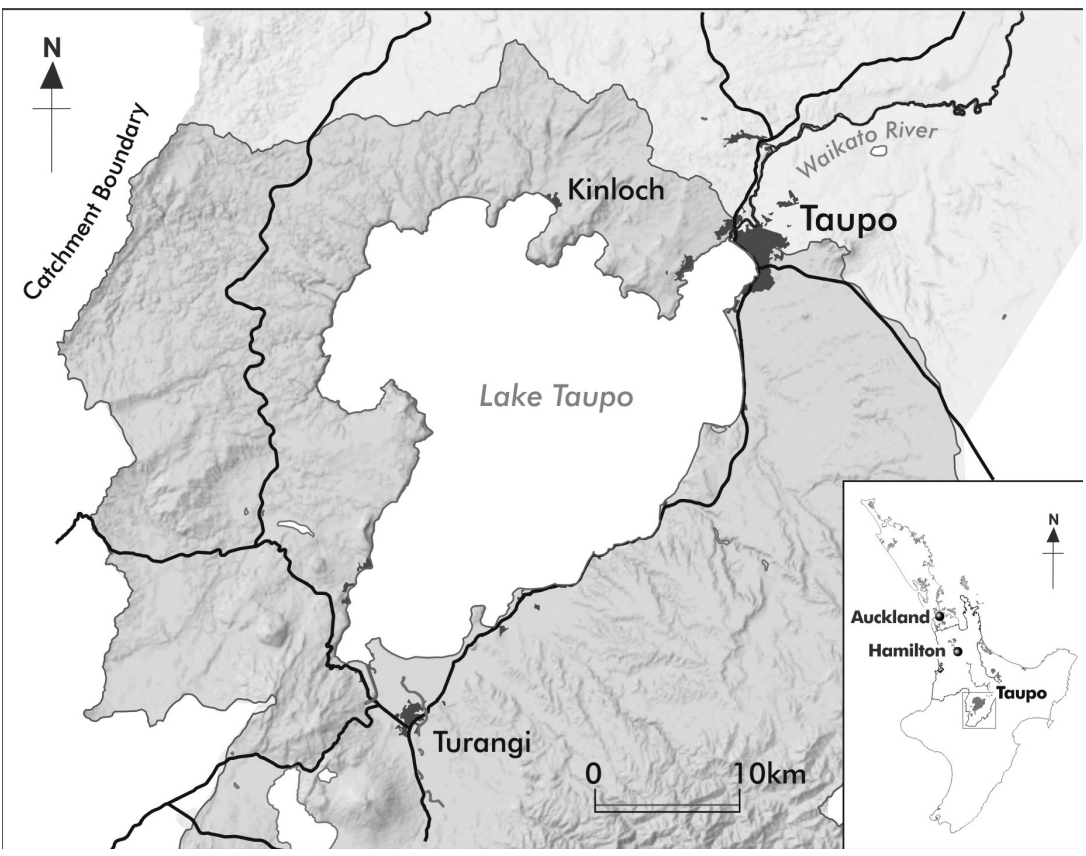

Figure 1: $\quad$ Lake Taupo study area.

Groundwater is the primary link for transport of nutrients derived from landuse activities to the lake. Streams in the study area are baseflow dominated (Schouten et al. [4]). It is important to predict nitrogen mass loading from groundwater to the lake and assess the lag in full land-use impact for lake management. There is strong community support for protection of the lake, which is a national icon. Maintaining ecological values for tourism is of greater economic benefit than risking degradation through further pastoral development. There is a current proposal to reduce nitrogen loading to the lake by $20 \%$. 


\section{Scope and approach}

Hydrogeologic study of the northern and western catchments included investigation of the geologic setting, aquifer hydraulic characteristics, water chemistry and stream-groundwater interaction. Of particular focus in this paper is information derived from groundwater age dating and numerical modeling of the northern catchment.

Numerous shallow monitoring wells were constructed to augment available wells in the sparsely developed area. Samples were taken for water chemistry and age dating, and pumping tests were carried out. The interaction between groundwater and streams was investigated by flow gauging, water quality sampling and tritium dating. Tracer injection tests were also undertaken as an initial study of denitrification. Direct groundwater seepage to the lake was studied at two locations, both at the shoreline and subsurface. The information derived was used to calibrate model predictions of mass transport and lag.

\section{Results}

\subsection{Hydrogeology}

The local geology which comprises young $(<0.4 \mathrm{Ma})$ locally derived rhyolitic pyroclastic formations can be broadly divided into three main groupings. The Whakamaru Group ignimbrites toward the west are poorly to moderately welded with low fracture density but flow is nevertheless generally fracture controlled. To their east is a more complex grouping considered loosely as 'rhyolitic pyroclastics'. These are both overlain by unwelded Oruanui Ignimbrite, which varies in thickness up to some $30 \mathrm{~m}$ Hadfield et al. [5].

Hydraulic conductivity for these simplified groups was estimated from pumping and slug testing, table 1 . Leakage estimates from pumping tests (which vary from 0.02 to $1 \times 10^{-4} \mathrm{~d}^{-1}$ ), measured vertical head differences ( 3 to $80 \mathrm{~m}$ ) and groundwater dating results, indicate variable connection between hydraulic units. Aquitards, such as paleosols, can however be locally important. Localised Whakaroa Rhyolite in the Kinloch area exhibits highly variable fracture dependent permeability ranging up to some $120 \mathrm{~m} \mathrm{~d}^{-1}$.

Table 1: $\quad$ Summary of aquifer hydraulic conductivity estimates $\left(\mathrm{m} \mathrm{d}^{-1}\right)$.

\begin{tabular}{|l|r|r|r|r|c|}
\hline \multicolumn{1}{|c|}{ Formation } & \multicolumn{1}{c|}{ Median } & \multicolumn{1}{c|}{ Mean } & $\begin{array}{c}\text { Std. } \\
\text { deviation }\end{array}$ & Minimum & Maximum \\
\hline Whakamaru & 0.01 & 0.26 & 0.66 & 0.007 & 2.02 \\
\hline Rhyolitic & 0.93 & 2.15 & 4.03 & 0.008 & 17.3 \\
\hline Oruanui Ignimbrite & 0.28 & 2.92 & 4.79 & 0.03 & 13.9 \\
\hline
\end{tabular}

Groundwater flow in the study area is consistent with topography although more subdued, fig. 2. The catchment divide is critical for management 
implications. There is no discrepancy evident between surface and groundwater catchments. A recharge regime exists generally throughout the area with a highly significant relationship between depth to static water level and well intake depth. The lake acts as a sink for groundwater, which is recharged from rainfall in the catchment.

\subsection{Streams and catchments}

The vast majority of stream reaches gain flow from groundwater. Although streams capture most groundwater before entering the lake, direct seepage makes significant contribution in some northern sub-catchments e.g. Mapara and Whangamata (about 80\%) (Piper [6]).

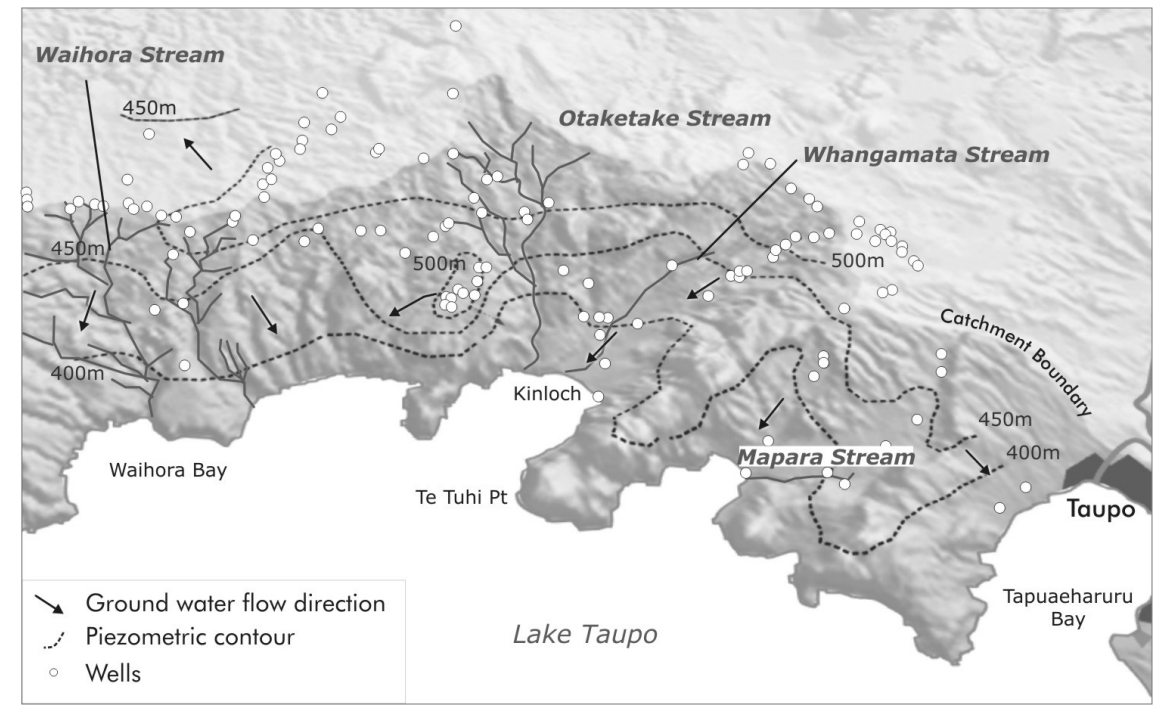

Figure 2: $\quad$ Lake Taupo's northern catchment and groundwater flow.

A substantial component of direct groundwater discharge to the lake from the Whangamata catchment was not accounted for in shallow beach seepage measurement (Hector [7]). Subsequent deeper investigation by divers found seepage zones in the lake to depths of about six metres accounted for this discrepancy. Algal mats associated with these seepage zones are inferred to take up much of the nitrogen from these inflows (Gibbs et al. [8]).

\subsection{Water chemistry}

Groundwater from 44 wells sampled for analysis of nutrients and major ion chemistry in 2000, showed relatively uniform sodium bicarbonate dominated groundwater typical of rhyolitic formation. There was, however, clear evidence of land-use impacts with nitrate-N commonly elevated above ambient condition, 
considered to be less than $1 \mathrm{~g} \mathrm{~m}^{-3}$. Very high nitrate-N $\left(\sim 36 \mathrm{~g} \mathrm{~m}^{-3}\right)$ at one well was found to result from point source contamination from a nearby woolshed.

Anaerobic or poorly aerobic conditions are indicated at about $15 \%$ of sites by the nitrate ammonia couple, presence of dissolved iron and manganese and Eh $\mathrm{pH}$ measurement. Investigation of denitrification by injecting nitrate and bromide into five available shallow piezometers, using the method of Trudell et al [9], inferred active denitrification may be rare due to a lack of available carbon. One site where denitrification was apparent is considered exceptional given the rare presence of peat (Environment Waikato unpublished results).

\subsection{Dating}

The age of groundwater in the northern and western Lake Taupo catchments was estimated by measuring the cosmosgenic isotope tritium (half life 12.3 years) in samples, as well as atmospheric trace gases, $\mathrm{CFCs}$ and $\mathrm{SF}_{6}$ ), which can resolve ambiguity. Age interpretation of groundwater depends on mixing processes underground. Groundwater and stream samples comprise a mixture, rather than a discrete age, reflecting variable flowpaths Maloszewski and Zuber [10]. It is useful to estimate not only the mean residence time (MRT) but also the fraction of water recharged since farming was established in the Taupo area in the 1960s $(\%$ young fraction (YF)). An indication of potential future nitrogen concentration may be obtained by considering an increase inversely proportional to the \% YF (Morgenstern et al [11]).

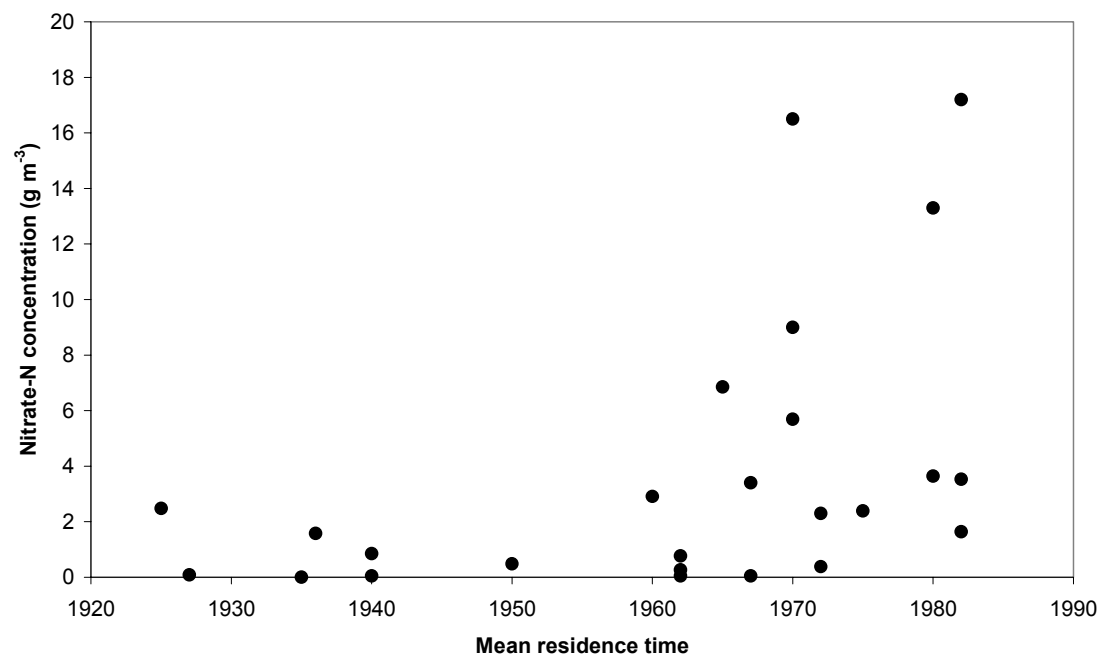

Figure 3: Nitrate-N concentration versus mean residence time (expressed as mean recharge date).

A total of 25 groundwater samples were analysed for tritium, CFCs and some for $\mathrm{SF}_{6}$ tracer concentrations. Mean residence times ranged from about 20 to 
75 years. Higher nitrate-nitrogen concentrations were shown to occur in younger groundwater, fig. 3. Not all of the young waters, however, have high nitrogen concentrations as the farming influence is not uniform.

Tritium samples were also collected from 11 streams mouths in the northern and western sub-catchments in 2001/02. MRT ranged from about 30 to 80 years with the oldest (and lowest\% YF) occurring in the 'rhyolitic pyroclastic', northeastern catchments e.g. Whangamata and Mapara. Streams in the western, Whakamaru Group, sub-catchments, which have steeper relief and higher rainfall were found to have younger MRTs. Potential future nitrogen loads from these streams are approximated on the basis of the percentage of farming input to come Vant and Smith [2]. Tritium sampled at multiple sites along streams within nine selected sub-catchments showed little age variation within catchments, inferring uniform drainage patterns (Piper [6]).

\subsection{Modeling}

A numerical groundwater model of the northern catchment was constructed using Modflow to simulate flow and MT3D for contaminant transport. Steady state flow and transient transport simulation were used to model future land-use impacts and consider management options

A three-layer model was used to enable vertical head distribution and vertical migration of contaminants to be explored. Model boundaries included a no flow catchment boundary, constant head lake boundary and river leakage to the Mapara, Whangamata, Otaketake and Waihora Streams. Water use was considered relatively insignificant and not included.

Inputs to the model included effective rainfall and solute (nitrogen) leaching from the ground surface. Recharge is estimated from available rainfall data, which shows a strong orographic influence. A uniform portion of evapotranspiration loss is assumed across the domain with resulting recharge ranging from 450 to $800 \mathrm{~mm} \mathrm{y}^{-1}$. Contaminant is added as spatially variable diffuse loading. This is based on characteristic nitrogen loading from mapped land-use with an assumed inverse linear relationship with effective rainfall. Work by Green and Clothier [12] indicates that a linear approximation may be reasonable.

Steady state flow conditions were calibrated with groundwater levels in 54 observation wells using the inverse method with a normalized root mean square of $<8 \%$ achieved. Flow was also matched in the four streams. Calibration of the flow model was most sensitive to changes in recharge, horizontal conductivity of deeper formation (layer 3), vertical hydraulic in the middle layer and horizontal conductivity in shallow formation (layer 1) respectively.

Model simulated groundwater velocities ranged from about 0.02 to $0.3 \mathrm{~m} \mathrm{~d}^{-1}$ and some groundwater travel times to the lake are in excess of 100 years (fig. 4). Horizontal hydraulic conductivity inputs range from $0.01 \mathrm{~m} \mathrm{~d}^{-1}$ to $100 \mathrm{~m} \mathrm{~d}^{-1}$ in the Kinloch area, consistent with field estimates.

Nitrate nitrogen was modeled as a conservative solute primarily because of the lack of observed denitrification in groundwater in the northern catchment. 


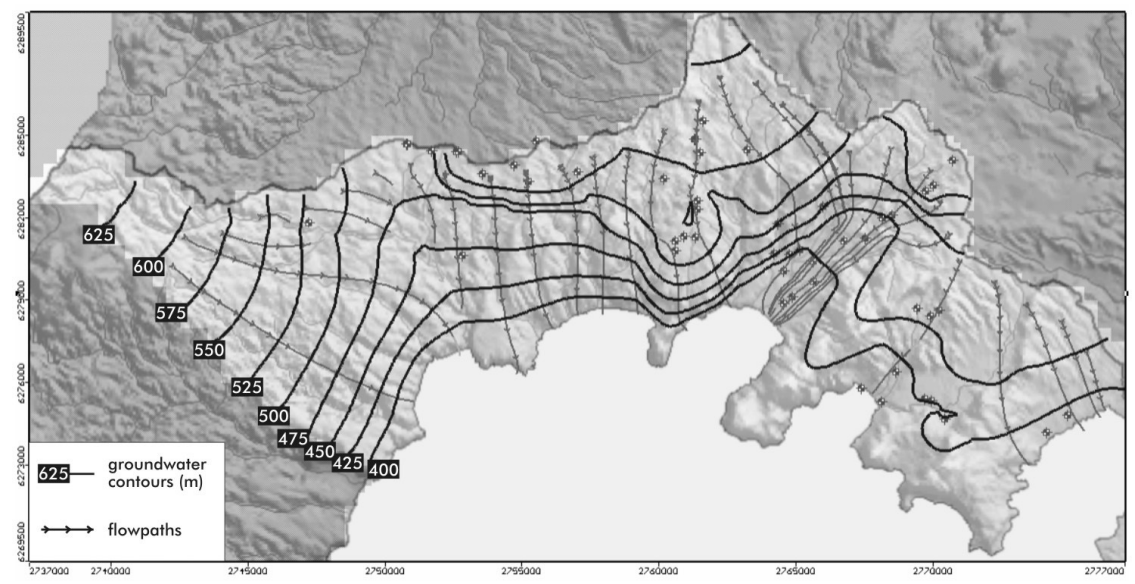

Figure 4: $\quad$ Modeled piezometric contours and flowpaths (10 year time steps).

Some denitrification is, however, inferred by water chemistry at some wells and at some wetland margins.

Ambient conditions were simulated by first running the model for 800 years with a loading rate of $2 \mathrm{~kg} \mathrm{~N} \mathrm{ha}^{-1} \mathrm{y}^{-1}$ estimated for native vegetation. Ambient recharge concentration ranged from $0.25 \mathrm{~g} \mathrm{~m}^{-3}$ to $0.44 \mathrm{~g} \mathrm{~m}^{-3}$. Typical loading rates used for drystock and dairy land-use were 12-14 $\mathrm{kg} \mathrm{N} \mathrm{ha}^{-1} \mathrm{y}^{-1}$ and $40-50 \mathrm{~kg} \mathrm{~N} \mathrm{ha}^{-1} \mathrm{y}^{-1}$ respectively Ledgard [13]. This translates into recharge concentrations ranging up to $7.3 \mathrm{~g} \mathrm{~m}^{-3}$.

Modeled concentrations after 35 years of simulated current land-use were compared with observations from 31 wells and historic water quality trends in the Mapara and Whangamata Streams. Highest nitrate concentrations of about $7 \mathrm{~g} \mathrm{~m}^{-3}$ were predicted in an area of dairy land use just west of Kinloch. Calibration using simplified land use data produced a normalized root mean square of $<16 \%$. Increasing dairy farm loading in the Kinloch area improved the fit to $<14 \%$ and removing four wells with groundwater chemistry indicating likely anaerobic condition improved the fit further to $<12 \%$. Although further improvement in calibration is achieved by manipulation of recharge concentration, emphasis was given to scenario and sensitivity testing using simplified land-use loading. The transport model was most sensitive in order of importance to changes in recharge concentration, conductivity, total porosity, recharge rate and dispersivity.

On the basis of the above assumptions, modelled ambient conditions indicate some 66 tonnes of nitrogen discharging from northern catchment groundwater annually with about 5,000 tonnes stored in aquifers. After 35 years of current farming about 150 tonnes of nitrogen would discharge annually with about 11,500 tonnes being stored in aquifers, fig. 6. Modeled continuation of land-use at the current intensity suggests nitrate- $\mathrm{N}$ transport from groundwater would equilibrate after about 250 years. Assuming conservative transport, some 


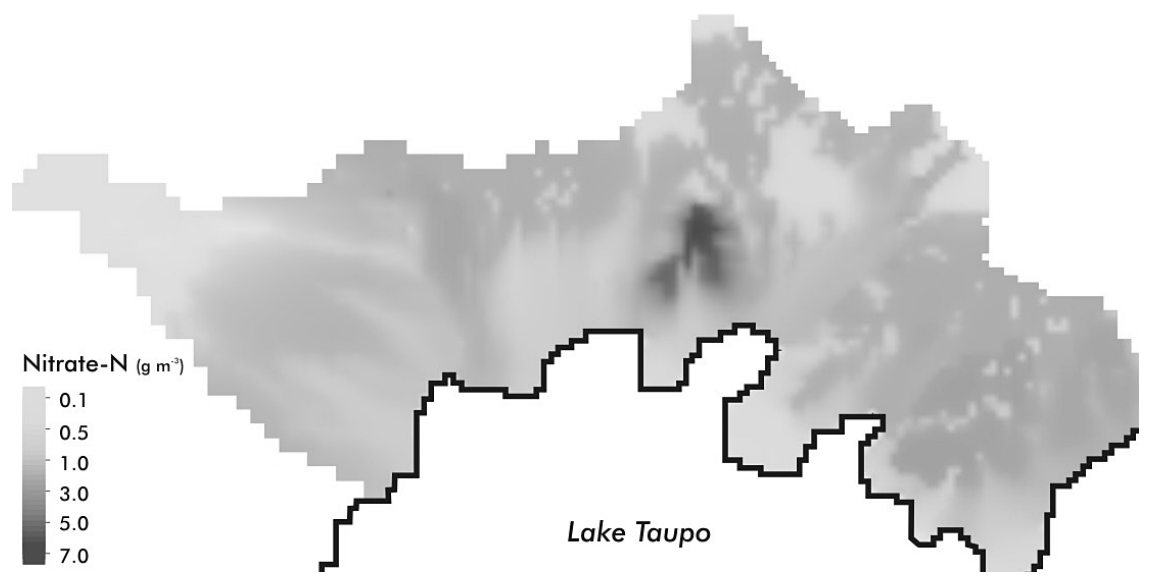

Figure 5: Nitrate-N concentration $\left(\mathrm{g} \mathrm{m}^{-3}\right)$ in shallow groundwater based on 250 years of current land-use.

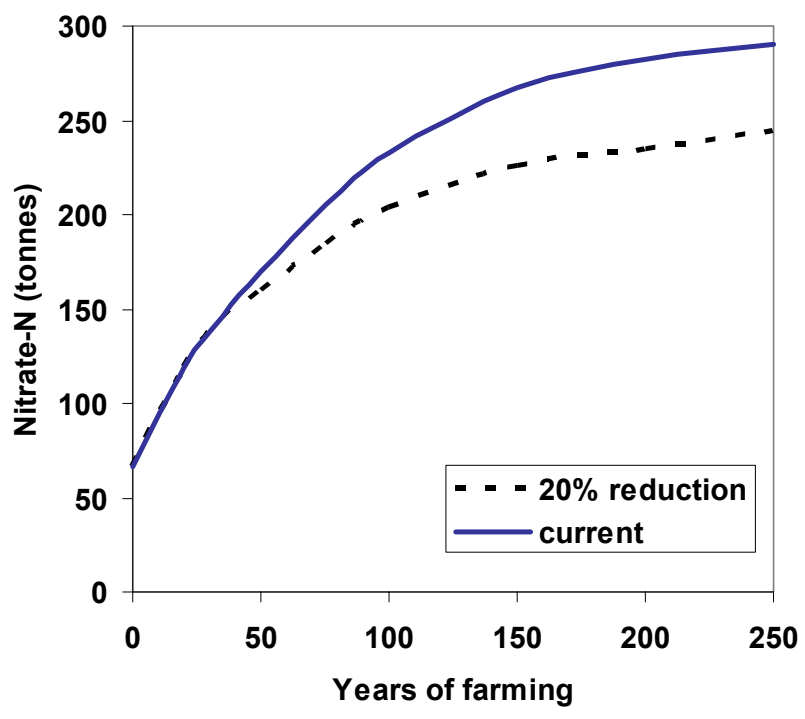

Figure 6: $\quad$ Mass flux of nitrate-N from groundwater.

300 tonnes of nitrate- $\mathrm{N}$ would migrate annually and 25,000 tonnes would be present in groundwater within the model domain.

The proposed policy initiative to reduce the manageable nitrogen load by $20 \%$ was also modeled by instantly reducing current land-use loading after 35 years. The resulting predicted curves show mitigated increases in nitrate-N loading from the northern catchment (fig. 6). Temporal concentration trends at individual wells are more variable, dependent on the extent to which concentrations had already stabilised. 
Stream nitrate-N concentrations were calculated from flow budgeting and mass flux of solute. Predicted concentrations for Whangamata Stream are of similar magnitude to those observed. The Mapara Stream concentration, by contrast, is over-predicted, which may be the influence of wetland denitrification in the head of that stream.

Modeling predicts a small immediate response in nitrate- $\mathrm{N}$ concentration to a $20 \%$ reduction in manageable nitrogen load to the Whangamata Stream but a longer-term increase. Nitrogen solute added to the model before and after the $20 \%$ reduction was differentiated to explain how an instantaneous response can occur in a stream with a mean residence time of about 80 years. This indicated that more than $10 \%$ of the nitrogen in the stream after one year is from new addition with there being about $45 \%$ after 45 years. The latter is about $20 \%$ higher than interpreted from tritium measurement.

\section{Discussion}

Models are inevitable simplifications of reality. Assumptions such as instantaneous farming development would accelerate effects, whereas exclusion of some streams from the model conversely increases average flowpaths and travel times. Although land-use loading was simplified for model input, a more detailed approach by Brown et al. [14] totaled within 10\%. Stream uptake of nitrogen is an important attenuation factor not addressed in this modeling but may be up to $50 \%$ Elliot and Stroud [15]. The combined application of dating and modeling is, however, effective in revealing the approximate extent of, and substantial delays in, land-use impacts. Modeling is particularly helpful in demonstrating the continuing slow build up of nitrogen mass in, as well as flux from, the groundwater system.

It has been estimated that total annual mass flux of nitrogen to Lake Taupo is about 1,200 tonnes. About $56 \%$ of this is from unmodified inputs such as rainfall and undeveloped land. A further 7\% is from water imported to the catchment for hydroelectric power generation. The approximately 470 tonnes (37\%) remaining is the manageable nitrogen load. The majority of this (about $31 \%$ or 58 tonnes) is from non-dairy pasture; about $5 \%$ from dairy farming and $2 \%$ from urban wastewater. Nitrogen load to the lake from current farming is expected to increase by at least $20 \%$ and up to $80 \%$ before equilibrium would be established according to Vant and Smith [2].

A proposed $20 \%$ decrease in manageable nitrogen load is proposed by regional government. A fund has been established to buy farmland to convert from pastoral to forestry or other low nitrogen leaching use. Landowners in the area would have their current nitrogen output capped and would only be able to increase this by offsetting elsewhere through a nitrogen trading system. Even before this initiative was promulgated, active conversion of farms to dairying was effectively stopped by market concerns about future land-use constraints. 


\section{Conclusions}

Water quality in Lake Taupo is starting to decline, essentially as a result of farming in its catchment. The lake, which is nitrogen limited, acts as a sink for groundwater migrating via baseflow dominated streams, as well as direct seepage. Elevated nitrate concentrations are part of evidence of land-use impacts on groundwater.

Tritium, $\mathrm{CFC}$ and $\mathrm{SF}_{6}$ dating of groundwater show higher nitrogen concentrations generally occur in groundwater receiving more recent recharge from farming, which developed in the area some 40 years ago. Mean residence times of groundwater samples analysed range from about 20 to 75 years.

Numerical modeling shows there is a considerable time lag ( $>100$ years) between land-use change and maximum nitrogen flux from groundwater. This reflects the time required to replace old pristine groundwater with nitrogen enriched water from farming. Annual nitrogen discharge from groundwater in the northern catchment is estimated from the modeling to be some 66 tonnes under ambient conditions, nearly 150 tonnes under current land-use and potentially some 300 tonnes if present farming activities continue. The amount of nitrogen stored in the groundwater system would also increase from about 5,000 tonnes under ambient conditions to some 11,000 tonnes under current land-use and potentially 25,000 tonnes once the full effects of current farming are realised.

Land-use effects in the Lake Taupo catchment, although considerable, are insidious, due to substantial lags and subtle changes. Groundwater modeling and dating are useful in revealing long term trends and impacts. Modeling indicates that a proposed initiative to reduce the manageable nitrogen load from the lake catchment by $20 \%$ would effectively mitigate the extent of increase otherwise expected in the northern catchment.

\section{References}

[1] Gibbs, M.M., 2006: Lake Taupo long-term monitoring programme 20042005, Environment Waikato Technical Report 2006/30, Environment Waikato, Hamilton.

[2] Vant, B. and Smith, P. 2004: Nutrient concentrations and water ages in 11 streams flowing into Lake Taupo. Environment Waikato, Hamilton. Technical Report, 2002/18R. 20 p.

[3] Ministry of Agriculture, 1997: Impacts of dairy conversion, Lake Taupo District. MAF Policy Paper 1997/9. Ministry of Agriculture, Wellington

[4] Schouten, C.J., Terzaghi, W., Gordon, Y., 1981: Summaries of water quality and mass transport data for the Lake Taupo catchment, New Zealand. Water and Soil Miscellaneous Publication 24, Ministry of Works, and Development, Wellington.

[5] Hadfield, J.C., Nicole, D.A., Rosen, M.R., Wilson, C.J.N. and Morgenstern, U., 2000: Hydrogeology of Lake Taupo Catchment - Phase 1. Environment Waikato, Hamilton 
[6] Piper, J.J., 2004: Surface water / groundwater interaction and catchment influence on waters entering Lake Taupo, New Zealand, Unpublished MSc thesis, Victoria University of Wellington.

[7] Hector, R.P., 2004: Investigation of direct groundwater and nutrient seepage to Lake Taupo. Unpublished MSc thesis, University of Waikato.

[8] Gibbs, M.M, Clayton, J. and Wells , R., 2005: Further investigation of direct groundwater seepage to Lake Taupo. NIWA report to Environment Waikato. 27 pp.

[9] Trudell, M.R., Gillham, R.W. and Cherry, J.A., 1986: An in-situ study of the occurrence and rate of denitrification in a shallow unconfined sand aquifer. Journal of Hydrology 83, 251-268.

[10] Maloszewski P, Zuber A, 1982: Determining the turnover time of groundwater systems with the aid of environmental tracers: I.: Models and their applicability, Journal of Hydrology., 57

[11] Morgenstern U, Reeves R, Daughney C, and Cameron S, 2004: Groundwater age, time trends in water chemistry, and future nutrient load in the Lakes Rotorua and Okareka area, GNS client report 2004/17.

[12] Green, S., and Clothier B., 2002: Modeling the impact of dairy farming on nitrate leaching in the Lake Taupo catchment. HortResearch report to Environment Waikato.

[13] Ledgard, S., 2000: Sheep and beef farming systems in the Lake Taupo catchment: Estimates of the effect of different management practices on nitrate leaching. Report for Environment Waikato. AgResearch.

[14] Brown, L., Hill, R.B., Singleton, P.L., (2002) Modelling surface water nitrogen. Proceedings of the New Zealand Soil Science Society Conference, Wellington December 2002.

[15] Elliot, A.H., and Stroud, M.J., 2001: Prediction of nutrient loads to Lake Taupo under various landuse scenarios. National Institute of Water and Atmospheric Research Ltd, 52 p. 